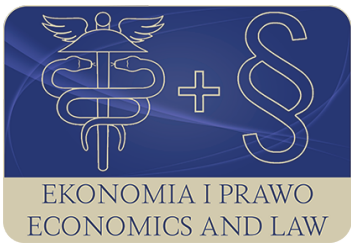

EKONOMIA I PRAWO. ECONOMICS AND LAW

Volume 18, Issue 1, March 2019

p-ISSN 1898-2255, e-ISSN 2392-1625

www.economicsandlaw.pl

EKONOMIA I PRAWO
ECONOMICS AND LAW

ORIGINAL ARTICLE

received 18.07.2018; revised 13.01.2019; accepted 31.03.2019

Citation: Godlewska, M. (2019). Do interactions between formal and informal institutions matter for productive entrepreneurship?. Ekonomia i Prawo. Economics and Law, 18(1): 17-28.

doi:10.12775/EiP.2019.002.

\title{
Do interactions between formal and informal institutions matter for productive entrepreneurship?
}

\author{
MAEGORZATA GODLEWSKA \\ Warsaw School of Economics, Collegium of Business Administration, Department of Administrative \\ and Financial Corporate Law, al. Niepodleglości 162, 02-554 Warszawa, Poland \\ ๑mgodlews@sgh.waw.pl \\ (iD) orcid.org/0000-0001-7413-0674
}

\begin{abstract}
Motivation: Institutional and Entrepreneurship theory pays attention to institutions and their influence on productive, unproductive and destructive entrepreneurship in transition economies. However, according to the literature, it is not only institutions that matter for productive entrepreneurship, but also the interaction between formal and informal

institutions. Moreover, transition economies needs the productive entrepreneurship

'to catch-up' with world leaders.

Aim: The aim of this paper is to advance institutional research through the development of a better understanding of the relation between formal and informal institutions and their influence on productive entrepreneurship in transition economies like CEECs.

Results: The paper demonstrates that strong formal and informal institutions, the 'invisible hand' of the state, as well as the complementary and accommodating relations between formal and informal institutions are necessary for productive entrepreneurship in transition economies.
\end{abstract}

Keywords: formal and informal institutions; productive entrepreneurship; transition economies; institutional asymmetry, interplay between institutions

JEL: D02; L26; O17; P37 


\section{Introduction}

Entrepreneurship is one of the most important factors of the economic growth (Acs et al., 2008; Baumol, 1990, 1993; Wennekers \& Thurik, 1999), especially in transition economies, like in Central and East European Countries (hereinafter $\mathrm{CEEC}^{\mathrm{I}}$ ), which want to 'catch-up' with world leaders. However, only productive entrepreneurship such as innovation lead to economic growth (Baumol, 1990), and unproductive entrepreneurship such as rent seeking or destructive entrepreneurship such as organized crime may lead to underground economic activities (Feige, 1997). Moreover, according to McMillan \& Woodruff (2002, p. 168), equally important are entrepreneurs who act in the transition economies as 'reformers' of ways the business is done.

The concept of the importance of institutions for productive entrepreneurship has its theoretical basis in New Institutional Economics. Institutions matter for entrepreneurship because they define the entrepreneurial capacity of each nation (North, 1990), as well as reduce uncertainty, transaction costs (Williamson, 1979) or provide conditions for productive entrepreneurship (Baumol, 1990, 1993). Moreover, not only do the institutions matter, but also the interaction between them is crucial for the support of productive entrepreneurship (Williams et al., 2017). However, investigations into the interaction between formal and informal institutions in the context of productive entrepreneurship in transition economies, which may have different forms and strengths, are significantly less frequently undertaken by scholars. This article attempts to fill this gap.

Central point of this paper is to present the results of institutions and entrepreneurship literature review. The main subject of interest concerns the development of a better understanding of the relation between formal and informal institutions and their influence on productive entrepreneurship, in the context of transition economies, like CEECs. This paper provides an understanding of how formal and informal institutions, the 'invisible hand' of the state, as well as the relations between formal and informal institutions may influence the productive entrepreneurship of CEECs. Moreover, full congruence between formal and informal institutions is very rare in institutional practice. Instead of congruence, the institutional asymmetry was observed between formal and informal institutions.

\section{Institutions and productive entrepreneurship in the context of transition economies: literature review}

Institutions are defined by North (1990) as any form of constraint that shapes human beings' interaction. North (1990) distinguishes between formal and in-

${ }^{1}$ CEECs is an OECD term for the group of countries comprising Albania, Bulgaria, Croatia, the Czech Republic, Hungary, Poland, Romania, the Slovak Republic, Slovenia, Estonia, Latvia and Lithuania. 
formal institutions. Formal institutions such as: formal rules, laws or constitutions are the visible 'rules of the game' enforced by governments. Informal institutions such as: constraints, customs, norms or culture are the invisible 'rules of the game' which are not legally enforced (North, 1990). Although not all scholars accept such definitions or distinctions between institutions ${ }^{2}$, in recent years there has been an enormous number of scientific publications concerning formal and informal institutions (see table 1), but a limited number of publications concerning interactions between institutions in the context of productive entrepreneurship and transition economies. Institutions (formal and informal) interact with each other 'in a variety of ways' (Helmke \& Levitsky, 2004, p. 728). This variety of interactions explains, according to Chavance (2008), the multiplicity of CEECs' transformation process pathways.

The CEECs, due to their communist past, didn't inherited from centrally planned systems entrepreneurship culture (Peng \& Heath, 1996). The majority of CEECs, which started the transformation process in the 90s, were lacking the necessary business infrastructure with the supporting formal and informal institutions (Aidis, 2005). Moreover, according to McMillan \& Woodruff (2002, p. 166), entrepreneurs play a central role in transition economies because of 'the welfare effects of entrepreneurship', like the creation of new jobs.

Furthermore, productive entrepreneurship requires not only strong and stable formal institutions (Baumol, 1990), but also strong informal constraints (Sauka \& Welter, 2007). Productive entrepreneurship refers 'to any activity that contributes directly or indirectly to the net output of the economy or to the capacity to produce additional output' (Baumol, 1993, p. 30). In addition, Aidis (2003), argues that in transition economies productive entrepreneurship is associated with individual ability and the willingness to find and use opportunities that will give economic growth.

Formal and informal institutions provide a variety of opportunities and incentives for entrepreneurs. If incentives promote productive entrepreneurship, entrepreneurs will adapt their activities to these opportunities. However, when the costs of illegal economic activities or rent-seeking behaviour are much lower than possible profit, entrepreneurs may engage in destructive or unproductive entrepreneurship (Aidis et al., 2008).

The literature, in the context of transition economies, highlight the existence of productive (Frye \& Shleifer, 1997; Sauka \& Welter, 2007; Wennekers \& Thurik, 1999; Williams et al., 2017), unproductive (Aidis et al., 2008; Feige, 1997; Williams et al., 2017) as well as destructive (Chilosi, 2001; Shleifer \& Vishny, 1993) forms of entrepreneurial business activities.

In addition, the transition process of CEECs highlight that institutions matter for productive entrepreneurship (Williams et al., 2017). However, according to Aidis (2003, p. 52), 'in transition economies productive entrepreneurship cannot be taken for granted' because in centrally planned systems entrepreneurial activities were focused on rent-seeking behaviour, which leads to unproduc-

\footnotetext{
2 See for example: Hodgson (2006) or Voigt (2012).
} 
tive and destructive entrepreneurship (Feige, 1997). According to the literature, it is not only institutions that matter for productive entrepreneurship, but also the interaction between formal and informal institutions, and the interplay between institutions determines the nature of productive entrepreneurship (Williams et al., 2017).

Finally, institutions influence the entrepreneurs' payoffs and allow for effort allocation between productive and unproductive entrepreneurship (Minniti, 2008).

\section{Methods}

This paper compares the theoretical and empirical achievements of New Institutional Economies with Entrepreneurship Theory in the context of transition economies like CEECs. Institutional theory pays attention to institutions and their influence on productive, unproductive and destructive entrepreneurship in transition economies (Aidis, 2003; Williams et al., 2017). In order to fulfil the aim of this paper Boolean keyword and subject term searches of Emerald, Google Scholar, JSTOR, ProQest and Scopus databases were performed by using search phrases reflecting the phenomena of Boolean search operators such as AND, NEAR and PHRASE between 25 and 30 June, 2018 and between 8 and 11 January, 2019.

The coexistence of the different interactions between formal and informal institutions in the context of transition economies and productive entrepreneurship was investigated. This allows the author, by using a detailed literature review, to demonstrate the specificity and the variety of relations between formal and informal institutions which may support, replace or undermine each other, as well as may influence the nature of entrepreneurship. The distribution of the search phrases in the Boolean search is presented in tables 1 and 2.

\section{Results: interaction between formal and informal institutions in the context of transition economies}

In the literature on the subject there is a lack of a consensus about the relation between formal and informal institutions. Some scholars, like Axelrod (1986, p. 1107) or McAdams (1997), highlight that informal institutions reinforce (complement) formal ones such as, for example, property rights. Other scholars, like Böröcz (2000, pp. 351-352) or Williams et al., (2017), stress that informal institutions undermine formal ones such as, for example, corruption or clientelism. While Pejovich (1999, p. 170), as well as Grzymala-Busse (2010) and Helmke \& Levitsky (2004) consider four different type of interaction between formal and informal institutions. However, Pejovich (1999) focuses on formal institutions and their impact on informal ones, while, Grzymala-Busse (2010) and Helmke \& Levitsky (2004), focus on the informal institutions and their im- 
pact on formal ones. Pejovich (1999) distinguishes four types of interaction between formal and informal institutions: (1) formal institutions suppress informal ones; (2) formal institutions conflict with informal ones; (3) formal institutions are neutral to informal ones or ignore them, and iv) formal institutions cooperate with informal ones. Meanwhile, Helmke \& Levitsky (2004) differentiate: (1) complementary informal institutions; (2) competing informal institutions; (3) accommodating informal institutions and (4) substitutive informal institutions. In addition, Grzymala-Busse (2010) following Helmke \& Levitsky (2004) typology of informal institutions similarly distinguishes four types of interaction, i.e.: (1) informal institutions replace formal ones; (2) informal institutions undermine formal ones; (3) informal institutions support formal ones, and (4) informal institutions compete with formal ones.

\subsection{Informal institutions support formal ones and vice versa}

Informal institutions have, according to Czech (2014, p. 317), 'the greatest power to shape social order' and may use this power for the reinforcement of formal rules that favour productive entrepreneurship such as commercial law, bankruptcy law, the law of contracts, antitrust law or the judicial system (Chilosi, 2001).

Helmke \& Levitsky (2004) highlight that informal institutions may reinforce formal ones by being complementary or accommodating. Complementary informal institutions 'fill in gaps' either by addressing contingences not dealt with in the formal rules or by facilitating the pursuit of individual goals within the formal institutional framework, as well as serve as the foundation for formal institutions (Helmke \& Levitsky, 2004, p. 728). On the other hand, accommodating informal institutions alter the effects of formal institutions without violating them, as they contradict the spirit of formal institutions (Helmke \& Levitsky, 2004, p. 729). Grzymala-Busse (2010, p. 311) argues that 'the elite competition generated by informal rules' influences which interaction between informal and formal institutions will dominate. Informal institutions may support formal ones by 'defining and expanding' formal institutions' domains or by 'providing incentives and information to follow formal institutions', like, for example, informal sanctioning or reporting to formal authorities about all non-compliance with formal rules (Grzymala-Busse, 2010, pp. 311, 318).

Pejovich (1999. p. 170) highlights another point of view and stress the opposite relation between formal and informal institutions, and argues that formal institutions might 'suppress but cannot change informal institutions'. Moreover, formal institutions may try to 'institutionalize' informal institutions, in order to better cooperate with them (Pejovich, 1999, p. 170). In such situations, formal institutions may support informal ones, like the development of property rights (Williamson \& Kerekes, 2011), or national corporate governance codes may comply with the business codes of listed companies, or with shared values among these companies (Godlewska \& Pilewicz, 2018). 


\subsection{Informal institutions replace formal ones and vice versa}

Informal institutions substitute formal ones in situations when formal institutions fail (North, 1990). Moreover, substitutive informal institutions 'achieve what formal institutions were designed, but failed to achieve', and emerge where formal institutions are weak or there is a lack of enforcement (Helmke \& Levitsky, 2004, p. 729). For example, informal institutions may replace formal ones in resource distribution via family and personal networks like clientelism, charity or nepotism (Grzymala-Busse, 2010, p. 318).

On the other hand, McAdams (1997, p. 346) argues that formal institutions might replace informal institutions like, for example, law that made seat belt use mandatory in the United States.

\subsection{Informal institutions undermine formal ones and vice versa}

Transition economies like CEECs inherited from the communist past weak informal institutions, such as a 'soviet-style corruption, a culture of non-compliance, employee theft, distrust of the government, and a highly skewed distribution of wealth and information' (Aidis, 2003, p. 31). Moreover, Helmke \& Levitsky (2004) highlight that informal institutions may undermine formal ones by competing with them. This may happen when formal institutions are not enough enforced, and outcomes are divergent. Furthermore, according to Grzymala-Busse (2010), informal institutions may undermine formal ones by exploiting loopholes of formal institutions, for example by using clientelism, patronage, or subletting and subcontracting, as well as directly contravening formal rules and eroding them by paying bribes instead of using a legal system. Weak informal institutions like corruption, tax evasion, clientelism, patrimonialism or clan politics (Aidis, 2003; Böröcz, 2000; Chavance, 2008; Helmke \& Levitsky, 2004) undermine the power of formal institutions. Furthermore, when informal institutions undermine formal ones, the transaction costs will rise, and that will diminish the establishment of potential new business transactions and the creation of wealth in the society (Meyer, 2001).

However, Pejovich (1999, p. 170) argues that formal institutions are 'in direct conflict with informal rules', like in the 'religions market' in Russia, where the law is used to restrict voluntary changes in informal rules. In such case formal institutions tend to undermine informal ones.

\subsection{Institutional asymmetry}

Institutional asymmetry takes place when formal institutions do not support informal ones and vice versa, in the form of 'misalignment between formal and informal institutions' (Williams et al., 2017, p. 7). In such cases entrepreneurial activity will be diminished (Williams \& Vorley, 2015) and informal institutions will not create and strengthen incentives to comply with formal institutions (Baumol, 1990; North, 1990). Moreover, entrepreneurs in transition econo- 
mies with a weak formal institutional environment have to deal with unstable regulations, which influences their effectiveness (Williams et al., 2017).

Williams et al. (2017) and Williams \& Vorley (2015) argue that institutional asymmetry (depending on the economic development level of each country) may cause the following consequences for productive entrepreneurship: (1) decreasing the ambition of entrepreneurs; (2) limiting the results of start-up programmes; (3) initiating difficulties with a culture averse to entrepreneurship; (4) skepticism of the wider public toward entrepreneurs; (5) poor perceptions of the opportunities and the ability to act on them by entrepreneurs.

In addition, institutional asymmetry due to limited congruence between formal and informal institutions in transition economies like Poland, Bulgaria, Croatia, Ukraine or Russia has undermined their entrepreneurship (Lubacha-Sember \& Godlewska, 2018; Williams et al., 2017; Williams, 2008). Furthermore, the 'grabbing hand' of the state and the institutional environment may hamper entrepreneurship if the government is above the law, the legal system does not work, and the state uses its power to extract rent and introduce predatory regulations for doing business, or introduce corruption (Frye \& Shleifer, 1997, p. 356).

\section{Conclusion}

Institutions, as well as the interactions between them, are important for the development of entrepreneurship and the institutional framework because they 'define the incentives for individuals to turn their ambitions into actions' (Caree \& Thurik, 2010, p. 587). Moreover, according to North (1994), if institutions reward only productive activities, in response to these incentives entrepreneurs move their activities from unproductive to productive ones.

Productive entrepreneurship according to the literature requires (see scheme 1): (1) strong formal institutions which are well enforced and stable, and clear regulations for entrepreneurs; (2) complementary or accommodating relations between formal and informal institutions that will allow the reinforcement of formal institutions by informal ones. This means that informal institutions will provide incentives for entrepreneurs to comply with formal rules; (3) the invisible hand of the state, where the government is not above the law and courts enforce contracts; (4) informal institutions are strong, and entrepreneurs have a positive attitude toward risk or cooperation, a high level of trust for institutions, as well as are directed by their own business codes of ethics; (5) personal characteristics which allow for the recognition of opportunities which exist in the surroundings, and for using them through productive entrepreneurial activity, and (6) macroeconomic stability, which supports the trading relationships between sellers and buyers. 


\section{References}

Acs, Z.J., Desai, S., \& Hessels, J. (2008). Entrepreneurship, economic development and institutions. Small Business Economics, 31(3). doi:10.1007/ sll187-008-9135-9.

Aidis, R. (2005). Entrepreneurship in transition countries: a review. Centre for the Study of Economic and Social Change in Europe Working Paper, 61.

Aidis, R. K. (2003). By law and by custom: factors affecting small and medium-sized enterprises during the transition in Lithuania. Amsterdam: Thela Thesis.

Aidis, R., Estrin, S., \& Mickiewicz, T. (2008). Institutions and entrepreneurship development in Russia: a comparative perspective. Journal of Business Venturing, 23(6). doi:10.1016/j.jbusvent.2008.01.005.

Axelrod, R. (1986). An evolutionary approach to norms. The American Political Science Review, 80(4). doi:10.2307/1960858.

Baumol, W. (1990). Entrepreneurship: productive, unproductive and destructive. Journal of Political Economy, 98(5).

Baumol, W. (1993). Entrepreneurship, management and the structure of payoffs. London: MIT Press.

Böröcz, J. (2000). Informality rules. East European Politics and Societies, 14(2). doi:10.1177/0888325400014002006.

Caree, M.A., \& Thurik, A.R. (2010). Impact of entrepreneurship on economic growth. In Z.J. Acs, \& D.B. Audretsch (Eds.), Handbook of Entrepreneurship Research. Second Edition. New York-Dordrecht-Heidelberg-London: Springer.

Chavance, B. (2008). Formal and informal institutional change: the experience of postsocialist transformation. The European Journal of Comparative Economics, $5(1)$.

Chilosi, A. (2001). Entrepreneurship and Transition. MOST: Economic Policy in Transitional Economies, 11(4). doi:10.1023/A:1015216429470.

Czech, S. (2014). Institutions as enabling constraints: a note on social norms, social change and economic development. Ekonomia i Prawo. Economics and Law, 13(2). doi:10.12775/EiP.2014.023.

Feige, E.L. (1997). Underground activity and institutional change: productive, protective and predatory behaviour in transition economies. In J.M. Nelson, C. Tilly, \& L. Walker (Eds.), Transforming post-communist political economies. Washington: National Academy Press.

Frye, T., \& Shleifer, A. (1997). The invisible hand and the grabbing hand. American Economic Review Papers and Proceedings, 87(2). doi:10.3386/w5856.

Godlewska, M., \& Pilewicz, T. (2018). The impact of interplay between formal and informal institutions on corporate governance systems: a comparative study of CEECs. Comparative Economic Research, 21(4). doi:10.2478/ cer-2018-0028. 
Grzymala-Busse, A. (2010). The best laid plans: the impact of informal rules on formal institutions in transitional regimes. Studies in Comparative International Development, 45(3). doi:10.1007/s12116-010-9071-y.

Helmke, G., \& Levitsky, S. (2004). Informal institutions and comparative politics: a research agenda. Pespectives on Politics, 2(4). doi:10.1017/ s1537592704040472.

Hodgson, G.M. (2006). What are institutions? Journal of Economic Issues, 40(1). doi:10.1080/00213624.2006.11506879.

Lubacha-Sember, J., \& Godlewska, M. (2018). The role of the local formal and informal institutions in microfirms' development: evidence from Poland. Economics and Sociology, 11(3). doi:10.14254/2071-789X.2018/11-3/3.

McAdams, R.H. (1997). The origin, development, and regulation of norms. Michigan Law Review, 92(2). doi:10.2307/1290070.

McMillan, J., \& Woodruff, C. (2002). The central role of entrepreneurs in transition economies. Journal of Economic Perspectives, 16(3). doi:10.1257/089533002760278767.

Meyer, K.E. (2001). Institutions, transaction costs and entry mode choice in Eastern Europe. Journal of International Business Studies, 31(2). doi:10.1057/ palgrave.jibs.8490957.

Minniti, M. (2008). The role of government policy on entrepreneurial activity: productive, unproductive or destructive. Entrepreneurship Theory and Practice, 32(5). doi:10.1111/j.1540-6520.2008.00255.x.

North, D.C. (1990). Institutions, institutional change, and economic performance. New York-Cambridge: Cambridge University Press.

North, D.C. (1994). Economic performance through time. The American Economic Review, 84(3).

Pejovich, S. (1999). The Effects of the Interaction of Formal and Informal Institutions on Social Stability and Economic Development. Journal of Markets e Morality, 2(2).

Peng, M.W., \& Heath, P.S. (1996). The growth of the firm in planned economies in transition: institutions, organizations, and strategic choice. Academy of Management Review, 21(2). doi:10.5465/amr.1996.9605060220.

Puffer, S. M., McCarthy, D.J., \& Boisot, M.H. (2010). Entrepreneurship in Russia and China: the impact of formal institutional voids. Entrepreneurship Theory and Practice, 34(3). doi:10.1111/j.1540-6520.2009.00353.x.

Sauka, A., \& Welter, F. (2007). Productive, unproductive and destructive entrepreneurship in an advanced transition setting: the example of Latvian small enterprises. In M. Dowling, \& J. Schmude (Eds.), Empirical entrepreneurship in Europe: new perspectives. Cheltenham: Edward Elgar.

Shane, S., \& Venkataraman, S. (2000). The promise of entrepreneurship as a field of research. Academy of Management Review, 25(1). doi: 10.2307/259271.

Shleifer, A., \& Vishny, R.W. (1993). Corruption. The Quarterly Journal of Economics, 108(3). doi:10.2307/2118402. 
Voigt, S. (2012). How (Not) to measure institutions. Journal of Institutional Economics, 9(1). doi:10.1017/s1744137412000148.

Wennekers, S., \& Thurik, R. (1999). Linking entrepreneurship and economic growth. Small Business Economics, 13(1). doi:10.1023/A:1008063200484.

Williams, C.C. (2008). Beyond necessity-driven versus opportunity driven entrepreneurship: a study of informal entrepreneurs in England, Russia and Ukraine. International Journal of Entrepreneurship and Innovation, 9(3). doi:10.5367/000000008785096647.

Williams, N., \& Vorley T. (2015). Institutional asymmetry: how formal institutions affect entrepreneurship in Bulgaria. International Small Business Journal, 33(8). doi:10.1177/0266242614534280.

Williams, N., Vorley, T., \& Williams, C.C. (2017). Entrepreneurship and institutions: the causes and consequences of institutional asymmetry. Washington: Rowman \& Littlefield International.

Williamson, C.R., \& Kerekes, C.B. (2011). Securing private property: formal versus informal institutions. The Journal of Law and Economics, 54(3). doi:10.1086/658493.

Williamson, O.E. (1979). Transaction-cost economics: the governance of contractual relations. Journal of Law and Economics, 22(2). doi:10.1086/466942.

\section{Acknowledgements}

Author contributions: author has given an approval to the final version of the article.

Funding: this research was fully funded by the Warsaw School of Economics, Collegium of Business Administration, Department of Administrative and Financial Corporate Law statutory sources.

Note: the results of this study were presented at Second Scientific Conference Institutions: theory and practice (June, 19-20 2018, Torun, Poland). 


\section{Appendix}

Table 1.

Number of search phrases results in selected scientific databases

\begin{tabular}{lcrrrr}
\hline \multicolumn{1}{c}{ Key word Boolean operators } & Google Scholar & Emerald & JSTOR & ProQest & Scopus \\
\hline formal institutions (FI) & 3710000 & 49775 & 139946 & 313348 & 12925 \\
institutional context & 3410000 & 69440 & 136433 & 339413 & 30732 \\
informal institutions (II) & 3230000 & 28772 & 63835 & 137865 & 6607 \\
cultural context & 3180000 & 88717 & 231875 & 293369 & 84688 \\
transition economies (TE) & 2420000 & 29895 & 34783 & 499553 & 20506 \\
institutional asymmetry (IA) & 606000 & 8140 & 8375 & 33931 & 1168 \\
productive entrepreneurship (PE) & 499000 & 6402 & 4835 & 30526 & 489 \\
\hline
\end{tabular}

Source: Own preparation based on search performed between 25 and 30 June, 2018.

Table 2.

Results of Boolean Search in selected scientific databases

\begin{tabular}{lrrrrr}
\hline \multicolumn{1}{c}{ Key word Boolean operators } & Emerald & \multicolumn{1}{c}{$\begin{array}{c}\text { Google } \\
\text { Scholar }\end{array}$} & JSTOR & ProQest & Scopus \\
\hline interaction between FI AND II AND TE / PE & $3195 / 383$ & $254000 / 48$ & $3191 / 380$ & $20065 / 3$ & $10 / 0$ \\
interaction between FI AND II NEAR TE / PE & $761 / 96$ & $130000 / 44$ & $1717 / 240$ & $959 / 0$ & $0 / 0$ \\
IA between FI AND II AND TE / PE & $460 / 81$ & $35700 / 7$ & $449 / 62$ & $3712 / 1$ & $2 / 0$ \\
IA between FI AND II NEAR TE / PE & $97 / 14$ & $25900 / 6$ & $235 / 32$ & $319 / 0$ & $0 / 0$ \\
II support FI AND TE / PE & $1247 / 172$ & $452000 / 43$ & $5199 / 526$ & $30487 / 4314$ & $8 / 1$ \\
II support FI NEAR TE / PE & $1101 / 127$ & $217000 / 39$ & $2646 / 316$ & $1142 / 0$ & $0 / 0$ \\
II undermine FI AND TE/ PE & $199 / 33$ & $114000 / 28$ & $1804 / 198$ & $7431 / 1$ & $1 / 0$ \\
II undermine FI NEAR TE / PE & $282 / 42$ & $66400 / 26$ & $1130 / 143$ & $319 / 0$ & $0 / 0$ \\
II replace FI AND TE / PE & $290 / 46$ & $163000 / 45$ & $1884 / 226$ & $11406 / 1$ & $2 / 0$ \\
II replace FI NEAR TE / PE & $626 / 82$ & $87100 / 41$ & $1246 / 165$ & $397 / 0$ & $0 / 0$ \\
FI support II AND TE / PE & $559 / 0$ & $492000 / 45$ & $5509 / 545$ & 312460 & $11 / 1$ \\
FI support II NEAR TE/ PE & $1158 / 134$ & $231000 / 41$ & $2768 / 321$ & $1149 / 0$ & $0 / 0$ \\
FI undermine II AND TE / PE & $1037 / 155$ & $120000 / 28$ & $65 / 9$ & $254 / 0$ & $0 / 0$ \\
FI undermine II NEAR TE / PE & $301 / 46$ & $69300 / 26$ & $1167 / 145$ & $23 / 14$ & $0 / 0$ \\
FI replace II AND TE / PE & $2101 / 261$ & $180000 / 47$ & $1970 / 232$ & $401 / 132$ & $0 / 0$ \\
FI replace II NEAR TE/PE & $651 / 86$ & $94400 / 43$ & $1281 / 165$ & $402 / 127$ & $0 / 0$ \\
\hline
\end{tabular}

Source: Own preparation based on Boolean Search performed between 25 and 30 June, 2018 and between 8 and 11 January, 2019. 


\section{Scheme 1.}

Productive, unproductive and destructive entrepreneurship in transition economies

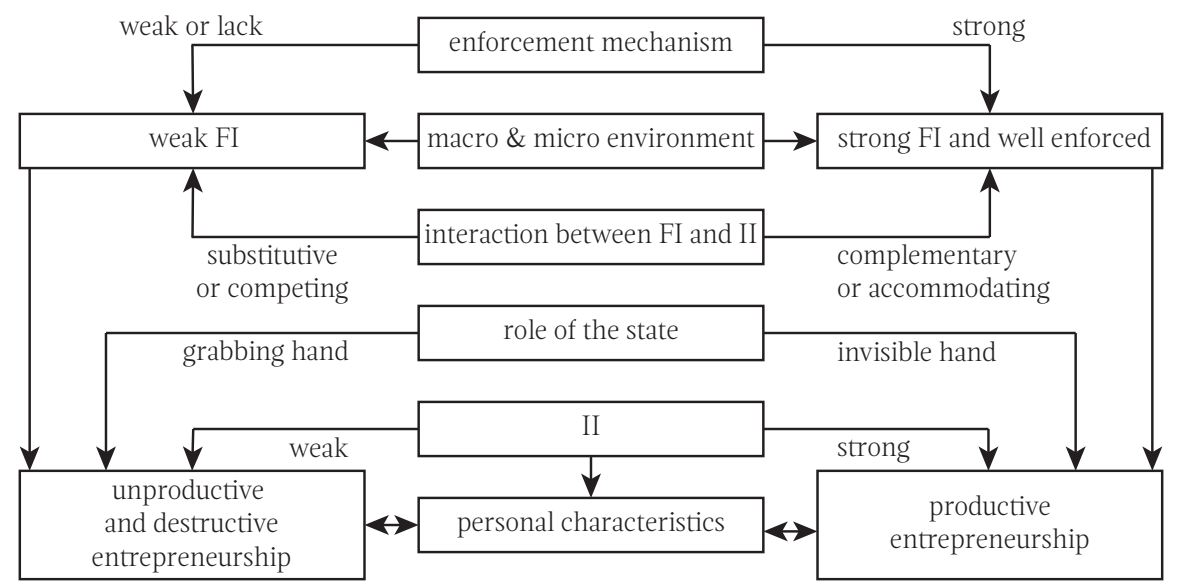

Source: Own preparation based on: Acs et al. (2008); Aidis (2003); Baumol (1990, 1993); Frye \& Shleifer (1997); Helmke \& Levitsky (2004); McMillan \& Woodruff (2002); North (1990); Puffer et al. (2010); Shane \& Venkataraman (2000); Wennekers \& Thurik (1999). 